\title{
Dongaláb-specifikus életminőség-kérdőív magyar adaptációja
}

\author{
Bohner-Beke Aliz ${ }^{1}$ - Kőnigné dr. Péter Anikó ${ }^{\text {. Vass Lívia }}{ }^{3}$ \\ Halasi Szabolcs ${ }^{6}$ - Kránicz János dr. ${ }^{4}$ - Pusztafalvi Henriette dr. ${ }^{5}$ \\ Pécsi Tudományegyetem, ${ }^{1}$ Egészségtudományi Kar, Egészségtudományi Doktori Iskola, \\ ${ }^{2}$ Bioanalitikai Intézet, ${ }^{3}$ Sporttudományi és Testnevelési Intézet, Sportbiológiai Tanszék, \\ ${ }^{4}$ Klinikai Központ, Általános Orvostudományi Kar, Ortopédiai Klinika, ${ }^{5}$ Egészségtudományi Kar, \\ Egészségfejlesztési és Népegészségtani Tanszék, Pécs \\ ${ }^{6}$ Újvidéki Egyetem, Magyar Tannyelvű Tanítóképző Kar, Szabadka (Subotica), Szerbia
}

\begin{abstract}
Bevezetés: A veleszületett strukturális dongaláb a leggyakoribb veleszületett lábdeformitás. Eredményesnek mondható kezelése ellenére is az érintett oldalon a lábszár atrophiájával, a láb hosszkülönbségével, funkcionális elmaradásával és esetleges fájdalmával kell számolnunk. Számos nemzetközi kutatás foglalkozik a dongalábbal élők életminőségének vizsgálatával, ennek ellenére hazánkban még nem történt ilyen felmérés. A betegalapú értékelést használják a kezelés eredményességének megállapításához, illetve a hagyományos és a Ponseti-féle kezelési módszer összehasonlításához. Célkitüzés: A szerzők célja a dongaláb esetén nemzetközileg legismertebb speciális életminőség-kérdőív, a 10 tételből és két alskálából (elégedettség, funkció) álló „Clubfoot Disease-Specific Instrument” (a továbbiakban: „Dongaláb Specifikus Mérőeszköz”) használatának engedélyeztetése, illetve szülői és gyermekváltozatának hazai adaptálása, majd a belső és külső validitás vizsgálata.

Módszer: A kérdőíveket 75 fó (44 fiú, 28 lány) töltötte ki három korcsoporti megoszlásban (12 év alattiak, 12-17,99 év közöttiek és 18 év felettiek); átlagéletkor: 12,45 év (2-44 év). Mérőeszközök: a „Dongaláb Specifikus Mérőeszköz” magyar nyelvű (korcsoportnak megfelelő) változatai; az általános életminőség mérésére az EQ-5D-3L magyar nyelvü verziója.

Eredmények: A „Dongaláb Specifikus Mérőeszköz” gyermek- és szülői változata megfelelő belső validitással rendelkezik (szülői: 0,872, gyermek: 0,923), illetve az egyes tételei és az EQ-5D-3L dimenziói között közepes és erős korrelációs értékek jellemzik az összefüggéseket a meglévő szignifikáns kapcsolatok mellett.

Következtetés: A mérőeszköz hazai adaptálása sikeresnek mondható, amely hozzájárult a dongalábbal élő betegek életminőségének megismeréséhez, és lehetőséget nyújt a gyakorlatban a kezelés eredményességének megítélésére. Orv Hetil. 2018; 159(31): 1269-1277.
\end{abstract}

Kulcsszavak: dongaláb, életminőség, betegségspecifikus adaptáció

\section{Hungarian validation of the Clubfoot Disease-Specific Instrument}

Introduction: Congenital structural clubfoot is the most common congenital deformity of the foot. Despite successful treatment, the affected side may present signs of athrophy, differences in length, functional maldevelopment and in some cases it may also result in pain. Although several international studies have been investigating the quality of life of individuals with clubfoot, no research has been done in Hungary. Patient-based assessment is used for the evaluation of the effectiveness of treatment and for the comparison of the traditional versus the Ponseti method. Aim: To gain permission for the use of the internationally most well-known Clubfoot Disease-Specific Instrument (hereafter: 'Clubfoot Specific Questionnaire') consisting of 10 items and two subscales, and furthermore, to adapt its parent and child-version for Hungary and to carry out the internal and external validity testing of the measure. Method: The Questionnaire was completed by 75 individuals ( 44 boys, 28 girls) belonging to three age groups (under age 12 , aged 12-17.99 years and those aged above 18 ); the mean age was 12.45 years (range: $2-44$ years). The measures used: the Hungarian version of the 'Clubfoot Specific Questionnaire' (adapted versions for the given age groups), and the Hungarian version of EQ-5D-3L to measure the general quality of life.

Results: Both the parent- and the child-version of the 'Clubfoot Specific Questionnaire' showed adequate internal validity (parent-version: 0.872 , child-version: 0.923 ); the individual items showed medium to strong correlations with the EQ-5D-3L dimensions besides the existing significant connections. 
Conclusion: The Hungarian adaptation of the measure proved to be successful. The validated questionnaire provides a further tool for the assessment of the quality of life of individuals with clubfoot and also for the evaluation of the success rate of therapies.

Keywords: clubfoot, quality of life, patient-specific adaptation

Bohner-Beke A, Königné Péter A, Vass L, Halasi Sz, Kránicz J, Pusztafalvi H. [Hungarian validation of the Clubfoot Disease-Specific Instrument]. Orv Hetil. 2018; 159(31): 1269-1277.

(Beérkezett: 2018. március 2.; elfogadva: 2018. április 19.)

\section{Rövidítések}

AOFAS = The American Orthopaedic Foot and Ankle Score; ASK = Activities Scale for Kids; CHQ = Child Health Questionnaire; DSI = Clubfoot Disease-Specific Instrument; FFI = Foot Function Index; FSIIr = Pediatric Functional Status; MOS SF-36 = Medical Outcome Study Short Form 36 Health Survey; PedsQL = Pediatric Quality of Life Inventory; PODCI = Pediatric Outcomes Data Collection Instrument; VRONY = Veleszületett Rendellenességek Országos Nyilvántartása

A veleszületett strukturális dongaláb a gyakori veleszületett rendellenességek közé tartozik, és mivel kezelése a legutóbbi időkig csak részben volt sikeresnek mondható, orvosi és társadalmi jelentősége nagy [1]. Az európai lakosság körében a gyakoriság 1-2 ezrelék közé tehető, amely hazánkban - a VRONY által 2004 és 2009 között regisztrált adatok alapján - 1,18 ezreléket mutat, vagyis ez évente átlagosan 116 új esetet jelent [2].

A nemzetközi szakirodalom az utóbbi időben elsősorban a dongaláb kezelésével, etiológiájával és a Ponsetitechnika eredményességének közlésével foglalkozik [36].

A kezelési eljárások összehasonlítása során már felmerül kérdésként az, hogy mi alapján hasonlítható össze két kezelési eljárás, valamint az is, hogy ki határozza meg a láb funkcióját: az orvos vagy a beteg legyen a kezelés végső bírája [7]? Az összehasonlítás szempontjából is fontos volt, hogy mely módszerrel és hogyan állapították meg a szakemberek az eredményességet.

A szakorvosokat a kezelés milyensége, a kutatókat pedig az életminőség objektív vagy szubjektív szempontú megítélése osztotta meg [8-12].

A tudományos közléseknek köszönhetően ma már a Ponseti-módszer határozza meg a kezelés elsődleges irányvonalát, és egyre inkább kezd előtérbe kerülni a megítéléskor a beteg szerepe. Ignacio Ponseti a korábbi (Kite nevéhez füződő) gipszelési és (kiterjedt lágyrész-) mútéti technikát módosította úgy, hogy a gipszelési technika esetén a talonavicularis ízület repozícióját helyezte a középpontba, és a mútétet minimalizálta a percutan teljes achillotomiával, majd pedig fél évben határozta meg a speciális orthesis (Denis Browne-sín) viselését [13].
A krónikus betegségek tekintetében egyre több magyar nyelvû speciális méróeszköz áll a szakemberek rendelkezésére, azonban jelenlegi ismereteink szerint veleszületett strukturális dongaláb-deformitás esetén Magyarországon nincs használatban sem általános, sem speciális életminőséget mérő kérdőív [14-19]. Ugyanakkor ennek fontossága indokolt lenne a betegcsoport egészségi állapotára és életminőségére irányuló megismerésünk miatt, továbbá a nemzetközi kitekintés is a használatukat igazolja, elsősorban a kezelés eredményességének megítélése és a kezelési módszerek összehasonlítása során történő alkalmazásukkor.

\section{Háttér}

A „Clubfoot Disease-Specific Instrument” (DSI) dongaláb-specifikus életminőség-skáláról Roye és mtsai 2001ben számoltak be először, amikor 46, mûtéti kezelésen átesett dongalábas betegrôl írtak tanulmányt, amelyben vizsgálatuk elsődlegesen a betegek visszajelzésére irányult. A hagyományos eredményeket (mozgástartomány, radiológai kritériumok), illetve a korábban már validált „FSIIr - Pediatric Functional Status” kérdőívet használták, melyből létrehozták a DSI-skálát [20].

Ezt követően Vitale és szerzôtársai (2005) tanulmányukban számoltak be a DSI és a CHQ használatáról 24, mútéti kezelésen átesett dongalábas beteg 16 éves utánkövetéses vizsgálata során, és azt kapták, hogy viszonylag magas a vizsgált fiatalok életminősége a mútét után, ha azonos korú, sportoló fiatalok életminőségéhez viszonyítják [21].

Noam Bor és mtsai (2009) 74 újszülött Ponseti-kezelésének utánkövetéses vizsgálatát végezték el, és a szerzók vizsgálták a DSI-kérdőív megbízhatóságát (Cronbach-alfa $=0,676)$. A szülő́k a kezelésre magas elégedettséget jeleztek, és a szerzők nem találtak összefüggést sem a bokamozgás, sem a brace-használat és a szülők elégedettsége között [22].

Dietz, Tyler, Leary és Damiano (2009) szintén a Roye által kifejlesztett DSI-kérdớvet használták, és alátámasztották a mutató hatékonyságát, amikor retrospektív kutatásuk során két kezelési csoportban (hátsó vagy posteromedialis feltáráson átesett és a Ponseti-technikával kezelt betegek) alkalmazták. Eredményeik szerint a mé- 
rőeszköz érzékeny az eltérő kezelési technikára és a betegség súlyosságára [23].

Grafés mtsai (2010) tanulmányukban 24 fős kiterjesztett lágyrész mútéten átesett, dongalábbal élő felnőtt betegcsoporthoz 48, korban megegyező egészséges felnőttet rendeltek kontrollcsoportként. A szerzők a DSI- mellett az SF-36-, az AOFAS- és az FFI-kérdőíveket használták. A kérdőíves felmérésből kiderült, hogy a betegek aktívak voltak a mindennapi tevékenységeiket tekintve, de fájdalomról számoltak be a járás, az állás, a lépcsőzés és az ugrás esetén [24].

Church és szerzôtársai (2012) a sebészi és a Ponsetitechnikával kezelt gyermekek retrospektív félidős eredményeit hasonlították össze több módszerrel és több validált kérdőívvel (PODCI-, ASK-, DSI-, Dimeglioskála). A tanulmány eredménye szerint a Ponseti-csoportban szignifikánsan jobb felmérési eredmények születtek a sebészivel szemben [25].

Radler és mtsai (2013) a Ponseti-kezelés középtávú eredményeit rögzítették, melyek szerint a DSI-pontszám $85,3(\mathrm{n}=65)$, a PODCI-pontszám $(\mathrm{n}=59)$ pedig 95,5 volt. A funkcionális pontszámok azt mutatták, hogy a Ponseti-módszer többnyire fájdalommentes lábat eredményez, és nem korlátozza az életkornak megfelelő tevékenységet [3].

Setersdal és mtsai (2016) összehasonlító tanulmányukban mutatták be a 2003 óta Norvégiában is bevezetésre kerülő Ponseti-módszer eredményességét hagyományos módszerrel kezelt 90 gyermek és Ponseti-módszerrel kezelt 115 gyermek vizsgálatával. A láb funkcionalitására vonatkozóan két kérdőívet használtak: „Functional Rating System for Clubfoot” kérdőívet és DSI-t. A szerzők a Ponseti-csoport esetében a bokaízület nagyobb moz- gásterjedelméről, jobb funkcióról, magasabb elégedettségről, kevesebb fájdalomról és az esetlegesen kialakuló másodlagos laposláb alacsonyabb számú megjelenéséről számoltak be [4].

\section{Célkitüzés}

A hagyományos ortopédiai vizsgálat nem terjed ki a dongalábbal kapcsolatos elégedettség és a funkció betegszempontú megismerésére, annak ellenére, hogy az életminőség-vizsgálatok szempontjából meghatározó a beteg szubjektív megítélése. A megismeréshez megbízható és rövid idő alatt felvehető mérőeszközre lenne szükség, ezért célunk a nemzetközileg bevált DSI-kérdőív magyar adaptációja volt.

\section{Módszer}

\section{A DSI adaptációja az alábbi lépésekből állt:}

1. engedélyeztetés; 2 . fordítás; 3 . visszafordítás; 4 . a viszszafordítás szerzői elfogadása; 5 . az elfogadott kérdőív kiküldése; 6. pszichometriai tesztelés [19, 18].

1. A DSI-kérdőív magyar adaptációjához elsődlegesen a szerző - dr. Benjamin Roye - hozzájárulására volt szükség.

2. A fordítás az úgynevezett kettős módszer módosított változata alapján történt 5 fós kétnyelvü csoporttal, és az egyes állítások szándékolt jelentéséhez való maximális közelítéssel.

3. A véglegesítés után az elkészült magyar nyelvü kérdőív visszafordítása angol nyelvre szintén egy (másik) 5 fös kétnyelvű csoporttal történt.

1. táblázat |A szülői Dongaláb Specifikus Mérőeszköz (DSI)

\begin{tabular}{|c|c|c|}
\hline Kérdés & $\begin{array}{l}\text { Vá- } \\
\text { lasz }\end{array}$ & Válaszlehetőségek \\
\hline (1) Mennyire elégedett gyermeke lábának állapotával? & & $\begin{array}{l}1=\text { teljesen elégedett, } 2 \text { = elégedett, } 3=\text { elégedetlen, } \\
4 \text { = nagyon elégedetlen }\end{array}$ \\
\hline (2) Mennyire elégedett gyermeke lábának alaki megjelenésével? & & $\begin{array}{l}1=\text { teljesen elégedett, } 2 \text { = elégedett, } 3=\text { elégedetlen }, \\
4 \text { = nagyon elégedetlen }\end{array}$ \\
\hline (3) Milyen gyakran csúfolják gyermekét a dongalába miatt? & & $1=$ soha, 2 = néha, 3 = általában, $4=$ mindig \\
\hline $\begin{array}{l}\text { (4) Milyen gyakran okoz problémát a gyermekének megfelelő } \\
\text { cipő beszerzése? }\end{array}$ & & $1=$ soha, 2 = néha, 3 = általában, $4=$ mindig \\
\hline $\begin{array}{l}\text { (5) Milyen gyakran okoz problémát a gyermekének tetsző cipőt } \\
\text { megtalálni? }\end{array}$ & & $1=$ soha, 2 = néha, 3 = általában, $4=$ mindig \\
\hline (6) Panaszkodott-e bármikor gyermeke az érintett láb fájdalmára? & & $1=$ igen, $2=$ nem \\
\hline (7) Milyen mértékben korlátozott gyermeke a járásban? & & $\begin{array}{l}1 \text { = egyáltalán nem korlátozott, } 2 \text { = kissé korlátozott, } \\
3 \text { = mérsékelten korlátozott, } 4=\text { nagyon korlátozott }\end{array}$ \\
\hline (8) Milyen mértékben korlátozott gyermeke a futásban? & & $\begin{array}{l}1 \text { = egyáltalán nem korlátozott, } 2 \text { = kissé korlátozott, } \\
3 \text { = mérsékelten korlátozott, } 4 \text { = nagyon korlátozott }\end{array}$ \\
\hline $\begin{array}{l}\text { (9) Milyen gyakran panaszkodik gyermeke fájdalomra intenzív } \\
\text { testmozgás során? }\end{array}$ & & $1=$ soha, 2 = néha, 3 = általában, $4=$ mindig \\
\hline $\begin{array}{l}\text { (10) Milyen gyakran panaszkodik gyermeke fájdalomra mérsékelt } \\
\text { testmozgás során? }\end{array}$ & & $1=$ soha, 2 = néha, 3 = általában, $4=$ mindig \\
\hline
\end{tabular}


4. Az 5 fós csoport angol nyelvre „visszafordított” kérdő́vei a szerző által elfogadásra kerültek (1. táblázat).

5. A „Statisztikai és tudományos adatgyưjtési kérelem” birtokában, a betegtájékoztató és a beleegyező nyilatkozat mellett, kiküldésre kerültek az egyes életkori csoportoknak megfelelő kérdőívcsomagok a betegek részére.

6. A kérdőív pszichometriai tesztelése során belső konzisztenciáját és szakmai validitását vizsgáltuk.

A külső validáláshoz viszonyításként a „EQ-5D-3L Egészségi kérdőív magyar nyelvü verzió Magyarország részére (Hungarian version for Hungary)" kérdőívet használtuk.

Az EQ-5D (EuroQoL) bármely betegség esetében használható, egészséggel kapcsolatos életminőség általános mérésére alkalmas, önkitöltős kérdőív. Az EQ-5D kérdőív gyorsan és egyszerüen kitölthető, valamint használata számos előnnyel bír. A regisztrációt követően (https://euroqol.org/) szabadon felhasználható, magyar nyelvi validált változata is ismert, szakirodalmi háttere kiterjedt, továbbá különböző betegségekben nagy betegszámú keresztmetszeti, követéses és randomizált kontrollált klinikai vizsgálatban is alkalmazták. A széles körû́ alkalmazhatóságnak köszönhetően összehasonlíthatóvá válnak egymástól távol álló betegségekben bekövetkező egészségiállapot-változások [26-28].

\section{A Dongaláb Specifikus Méróeszköz (DSI) értékelése}

A 10 tételből álló mérőeszköz két alskálából áll: elégedettség- és funkcióalskála. A betegek válaszai 1-től 4-ig terjedtek, ahol az l-es jelenti a „legjobbat” (például „teljesen elégedett”, „soha nem okoz problémát a megfelelő cipő beszerzése” stb.) és a 4-es a legrosszabbat („nagyon elégedetlen”, „mindig problémát okoz a megfelelő lábbeli beszerzése” stb). Az 1-től 4-ig terjedő pontok 0-tól 100-as skálára történő lineáris transzformációja ( 1 = $100,2=66,66,3=33,33,4=0$ ) az értelmezhetőség és a különböző skálák egymáshoz való hasonlíthatósága miatt is célszerünek bizonyul. Az $1=$ igen és $2=$ nem kérdés kódja változik a fentihez képest; az $1=0$ és a $2=100$ pontot ér. Az összesítést követően a tételek számával szükséges osztani a kapott értéket, aminek megfelelően 100 pont volt a maximális, 0 pedig a minimális pontszám, vagyis minél magasabb a pontszám, annál jobb a beteg megítélése $[4,23]$.

A DSI-kérdőív 6., fájdalomra irányuló kérdése az értékelés során többször jelentett problémát. Amíg kilenc tétel esetén a betegek válaszai 1-4-ig terjedhetnek, és sokkal pontosabban jellemezhető az adott terület, addig a fájdalom esetén két válaszra szorítkozhatunk: 1 = igen, vagyis fáj, és $2=$ nem, nem fáj, tehát nincsenek további árnyalt változatai. Ez a pontozás esetén is problémát jelent $(1=0,2=100)$, mivel vagy 0 , vagy 100 pontot adhat valaki, és ez a szélsőségeket erősíti, illetve akkor is
0 pontot jelent, ha egyszer fájt már valaha az érintett lába, és akkor is, ha már a járás is fájdalmas.

\section{Mintavétel és résztvevők}

A vizsgálati csoportot a Pécsi Tudományegyetem, Klinikai Központ, Ortopédiai Klinika beteganyaga alkotta. A retrospektív vizsgálatot a Pécsi Orvostudományi és Egészségtudományi Központ Regionális Kutatásetikai Bizottsága engedélyezte (PTE/40288/2017). 189 kiküldött levélből 27 érkezett vissza felbontás nélkül, és 75 értékelhetően. A 75 fós, strukturális dongalábbal élő vizsgálati csoportban 44 fiú $(61,1 \%)$ és 28 lány $(38,9 \%)$ volt (3 hiányzó adat). A veleszületett dongaláb esetében a fiú : lány arány $2: 1$, amely fiútúlsúly a vizsgálati csoportban is megmutatkozik, de nem kétszeres, hanem másfélszeres arányban. A betegek átlagéletkora 12,45 év volt (2-44 év, szórás: 9,9 év).

Vizsgálati célunk megvalósításához három életkori csoportot határoztunk meg:

Az 1. csoportot alkotják a 2-11,99 év közötti gyermekek 38 fơvel (50,7\%), akiknek az életminőségéról a szülő által közvetett (proxy) adatok nyerhetők.

A 2. csoportot a 12-17,99 év közötti gyermekek alkotják 20 fơvel (26,27\%), akik már önállóan is képesek nyilatkozni a saját állapotukról. A második csoport esetében egy dongaláb-specifikus életminőség-kérdőívet (DSI self-reported = DSI saját) a dongalábbal élő gyermek, és egyet az egyik szülő is kitöltött gyermekéről (DSI proxyreported = DSI szülőii) az EQ-5D-3L kérdőív mellett.

A 3. csoportot a felnött korú (18-44 év, medián: 22 év, átlag: 26,59 év), dongalábbal élōk alkotják 17 fơvel (22,7\%), és nyilatkoznak életminőségükról a DSI- és az EQ-5D-3L kérdőív segítségével. A betegek részére kiküldött DSI-kérdőívek a három csoportban minimális különbséget mutattak, és csak a megfogalmazásban tértek el, például: „Mennyire elégedett lábának állapotával?”, vagy „Mennyire elégedett gyermeke lábának állapotával?"

A 75 fós vizsgálati csoportban 55 fó $(73,3 \%)$ esetében a hagyományos kezelést (gipszredressio és kiterjesztett lágyrészmútét), 20 fó $(26,7 \%)$ esetében pedig a ma már elterjedtté vált Ponseti-kezelést alkalmazták. A kérdőíves vizsgálat mellett 18 fó esetén a szubjektív megítélés kiegészült az objektív mérésekkel is, azonban ezen adatok és eredmények a jelen közleményben nem kerülnek említésre.

\section{Statisztikai eljárás}

A statisztikai elemzéseket az IBM SPSS Statistics 22-es programmal végeztük. A kérdőívek eredményeinek ismertetésekor az átlagok és a mediánok közötti különbözőség a minták nem normális eloszlására hívták fel a figyelmet, ezért a két változó közötti szignifikáns különbségek elemzéséhez a Mann-Whitney-féle próbát alkalmaztuk. A DSI-tételek és az EQ-5D egyes dimenzi- 
2. táblázat |A self-reported és a proxy-reported DSI tételenkénti ponteredményei

\begin{tabular}{|c|c|c|c|c|c|}
\hline \multirow[t]{2}{*}{ DSI-tétel } & \multirow[t]{2}{*}{ DSI rövid megnevezése } & \multicolumn{2}{|c|}{ Self-reported $(\mathrm{n}=37)$} & \multicolumn{2}{|c|}{ Proxy-reported $(\mathrm{n}=58)$} \\
\hline & & Átlag \pm SD & Medián & Átlag \pm SD & Medián \\
\hline 1 . & Elégedettség a láb állapotával & $59,46 \pm 27,37$ & 66,67 & $64,91 \pm 27,76$ & 66,67 \\
\hline 2. & Elégedettség az alaki megjelenéssel & $49,55 \pm 32,03$ & 66,67 & $61,40 \pm 30,07$ & 66,67 \\
\hline 3. & Csúfolás a dongaláb miatt & $71,17 \pm 32,54$ & 66,67 & $88,89 \pm 23,85$ & 100,0 \\
\hline 4. & Megfelelő cipő beszerzése & $44,14 \pm 38,53$ & 33,33 & $52,63 \pm 36,70$ & 66,67 \\
\hline 5. & Tetsző cipő beszerzése & $47,75 \pm 37,30$ & 66,67 & $61,99 \pm 36,43$ & 66,67 \\
\hline 6. & Lábfejfájdalom & $24,32 \pm 43,49$ & 0,0 & $40,35 \pm 49,49$ & 0,00 \\
\hline 7. & Korlátozottság a járásban & $74,77 \pm 31,82$ & 100,0 & $81,29 \pm 28,88$ & 100,0 \\
\hline 8. & Korlátozottság a futásban & $61,26 \pm 36,44$ & 66,67 & $68,42 \pm 34,74$ & 66,67 \\
\hline 9. & Panaszok intenzív mozgás során & $54,95 \pm 35,32$ & 66,67 & $70,76 \pm 27,51$ & 66,67 \\
\hline 10. & Panaszok mérsékelt mozgás során & $74,77 \pm 32,78$ & 100,0 & $83,63 \pm 24,49$ & 100,0 \\
\hline
\end{tabular}

DSI = Dongaláb Specifikus Mérőeszköz

ói közötti összefüggéseket Spearman-féle rangkorrelációval elemeztük. A korrelációs együtthatót gyengének tartottuk, ha rs $<0,3$, közepesnek, ha rs $=0,3-0,6$ és erősnek, ha rs>0,6 volt. A kérdőívek belső konzisztenciájának vizsgálatára a Cronbach-alfa-értékeket 0,7 fölött tartottuk elfogadhatónak [29].

\section{Eredmények}

\section{A saját kitöltésü (self-reported) DSI-kérdöivek eredményei}

Az egyes DSI-tételek az alábbi átlagos pont- és medián értékkel jellemezhetők (2. táblázat):

Az életminőség-csökkenés a dongaláb hatására a „lábfejfájdalom" területen a legkifejezettebb, és ezt követi a „megfelelő cipő beszerzése”, de legkevésbé a járást és a mérsékelt testmozgást korlátozza/befolyásolja a deformitás. A self-reported DSI tételei és a nem, az érintettség vagy a kezelés módja között nincs szignifikáns különbség az egyes csoportok között, az életkori csoportokat tekintve viszont a 6 . tétel esetén igazolható volt $(\mathrm{U}=$ $117,00 ; Z=-2,173 ; p=0,030)$.

\section{A szülöi (proxy-reported) DSI-kérdöívek eredményei}

A szülői válaszokat az egyes DSI-tételeket tekintve szintén a 2. táblázat tartalmazza, melyek az átlagos pont- és medián értékkel jellemezhetők. A szülői visszajelzések alapján az életminőség-csökkenés a dongaláb hatására a „lábfejfájdalom” és a „megfelelő cipő beszerzése” területeken a legkifejezettebb, és a legkevésbé érintett a „csúfolás” és a „mérsékelt testmozgás során jelzett panaszok” tekintetében.

A proxy-reported DSI esetén a 10 tételből 6 kérdésnél és a teljes DSI esetén is szignifikáns különbséget talál- tunk az életkori csoportokat tekintve $(\mathrm{U}=173,00 ; \mathrm{Z}=$ $-3,189 ; \mathrm{p}=0,001)$. További szignifikáns különbség igazolható a nemek tekintetében az 1 . tétel $(\mathrm{U}=234,50$; $\mathrm{Z}=-1,951, \mathrm{p}=0,05)$ és a 3 . tétel $(\mathrm{U}=250,50 ; \mathrm{Z}=$ $-2,047 ; \mathrm{p}=0,04)$ esetén. A (proxy-reported) teljes DSI-

3. táblázat |A saját és a szülői DSI-kérdőív pontértekeinek összehasonlítása a 2. korcsoport esetén

\begin{tabular}{|c|c|c|c|c|}
\hline $\begin{array}{l}\text { DSI- } \\
\text { tétel }\end{array}$ & DSI rövid megnevezése & $\begin{array}{l}\text { (Self) pont } \\
(\mathrm{n}=20)\end{array}$ & $\begin{array}{c}\text { (Proxy) } \\
\text { pont } \\
(\mathrm{n}=20)\end{array}$ & $\begin{array}{l}\text { Pont- } \\
\text { különbség }\end{array}$ \\
\hline 1. & $\begin{array}{l}\text { Elégedettség a láb } \\
\text { állapotával }\end{array}$ & 59,65 & 54,39 & $-5,26$ \\
\hline 2. & $\begin{array}{l}\text { Elégedettség az alaki } \\
\text { megjelenéssel }\end{array}$ & 52,63 & 50,88 & $-1,75$ \\
\hline 3. & $\begin{array}{l}\text { Csúfolás a dongaláb } \\
\text { miatt }\end{array}$ & 71,63 & 73,68 & $+2,05$ \\
\hline 4. & $\begin{array}{l}\text { Megfelelő cipő } \\
\text { beszerzése }\end{array}$ & 38,60 & 33,33 & $-5,27$ \\
\hline 5. & Tetsző cipő beszerzése & 42,11 & 42,11 & 0 \\
\hline 6. & Lábfejfájdalom & 5,26 & 15,79 & $+10,53$ \\
\hline 7. & $\begin{array}{l}\text { Korlátozottság a } \\
\text { járásban }\end{array}$ & 75,44 & 75,44 & 0 \\
\hline 8. & $\begin{array}{l}\text { Korlátozottság a } \\
\text { futásban }\end{array}$ & 61,40 & 57,89 & $-3,51$ \\
\hline 9. & $\begin{array}{l}\text { Panaszok intenzív } \\
\text { mozgás során }\end{array}$ & 50,88 & 52,63 & $+1,75$ \\
\hline 10. & $\begin{array}{l}\text { Panaszok mérsékelt } \\
\text { mozgás során }\end{array}$ & 75,44 & 73,68 & $-1,76$ \\
\hline \multicolumn{2}{|c|}{$\begin{array}{l}\text { DSI elégedettségi alskála } \\
\text { (1-5. tétel) átlagértéke }\end{array}$} & 52,98 & 50,88 & $-2,1$ \\
\hline \multicolumn{2}{|c|}{$\begin{array}{l}\text { DSI funkcióalskála } \\
\text { (6-10. tétel) átlagértéke }\end{array}$} & 53,68 & 68,77 & $+15,09$ \\
\hline \multicolumn{2}{|c|}{ DSI-átlagérték } & 53,33 & 59,82 & $+6,49$ \\
\hline
\end{tabular}

DSI = Dongaláb Specifikus Mérőeszköz 
kérdőív ( $\mathrm{U}=213,50 ; \mathrm{Z}=-2,622 ; \mathrm{p}=0,009)$, a két alskála (elégedettség: $U=236,00 ; Z=-2,250 ; p=$ 0,024 , funkcióalskála: $U=202,00 ; Z=-2,835 ; \mathrm{p}=$ $0,005)$, illetve 5 tétele $(3 ., 5 ., 6 ., 9 ., 10$.$) és a kezelés$ módjai között is szignifikáns különbség mutatkozik.

\section{A saját (self-reported) és szülöi (proxy-reported) speciális életminöség (DSI)-kérdöí átlagértékeinek összehasonlitása a 2. korcsoport esetén}

A szülők és az érintettek válaszainak különbözőségére irányuló vizsgálat a 2 . korcsoport esetén indokolt (3. táblázat).

A 12-18 éves korú gyermekek és szüleik válaszai a két alskálát tekintve ellentétes irányt mutatnak, de összességében 6,49 ponttal jobbnak értékelik a szülők a gyermekeik életminőségét, mint ahogyan ők vélekednek erről. A két alskála közül az elégedettségi alskála átlagértéke 2,1 ponttal kevesebb, mint a gyermekek válaszai, de a funkcióalskála átlagértéke 15,09 ponttal magasabb értéket mutat, vagyis a szülők kevésbé elégedettek, főként gyermekeik lábának állapotával kapcsolatban, de a funkciót jobbnak értékelik, ami elsősorban a fájdalom helytelen megítélésével függ össze.

A különböző mértékú és irányú eltéréseket figyelembe véve a fájdalomra vonatkozó eltérés a leginkább meghatározó, ami a funkcionális alskálán is megjelenik, illetve ezáltal a teljes mérőeszközt is a kedvezőbb szülői megítélés jellemzi.

\section{A saját (self-reported) és a szülöi (proxy-reported) DSI-kérdöívek összefüggéseinek vizsgálata}

A két speciális életminőség-kérdőív és az azok alskálái közötti összefüggések vizsgálatakor kapott magas Spearman-korrelációs együtthatók a szülői és a saját elégedettség- és a funkcióalskála és a két teljes skála közötti szoros szignifikáns korrelációt ( $\mathrm{rs}=0,870 ; \mathrm{n}=19 ; \mathrm{p}<0,001$ ) igazolják.

\section{A DSI belsö konzisztenciájának vizsgálata}

A saját (self-reported) DSI- és a szülői (proxy-reported) DSI-kérdőív belső megbízhatóságának vizsgálatára a Cronbach-alfa-koefficienst használtuk a két alskála és a teljes kérdőív esetén. A saját (self-reported) DSI-kérdőív Chronbach-alfa-értéke az elégedettségi alskálát tekintve 0,907, a funkcióalskálát tekintve 0,826 , valamint a teljes kérdőívnél 0,923 ez az érték. A szülői (proxy-reported) DSI-kérdőívnél mért értékek az elégedettségi alskálán 0,85 , a funkcióalskálán 0,738 , és a teljes kérdőív 0,872 es Chronbach-alfa-értékkel rendelkezik. A magas értékek arról adnak bizonyítékot, hogy minden állítás meg- felelő súllyal vesz részt a kérdőív végső értékének kialakításában. A DSI-kérdoóív magyar nyelvű változatainak minden állítása megfelelő értéket mutatott a kérdőív teljes skáláján belül.

\section{$A z E Q-5 D-3 L$ kérdöív eredményei}

A kérdőív leíró részéból számított EQ-5D-index átlagértéke a vizsgálati csoportban $0,89(\mathrm{n}=37, \min =0,27$, $\max =1,00$, szórás $=0,17)$, továbbá nem volt szignifikáns összefüggés az indexértékek és az életkor, a nem, illetve az érintettség között.

\section{Az EQ-5D és a DSI közötti összefüggések vizsgálata}

A DSI-tételek (saját megítélésű/self-reported) és az EQ5D egyes dimenziói közötti összefüggéseket Spearmanféle rangkorrelációs számítással vizsgáltuk, amelynek együtthatóit mutatja a 4. táblázat.

A táblázatban magas a szignifikáns korrelációk száma, és közepes, illetve erős korrelációs értékek jellemzik az összefüggéseket (a meglévő szignifikáns kapcsolat esetén).

A DSI egyes tételei, alskálái és a teljes skála, valamint az EQ-5D indexértékei közötti össszefüggések korrelációs együtthatóit szintén a 4. táblázat tartalmazza.

A DSI-kérdőív és az EQ-5D indexértékei között magas korrelációs együtthatókat találtunk, amelyek a két mérőeszköz egyes tételei, alskálái és a dimenziók közötti együtt mozgást bizonyítja. Összességében a legnagyobb korrelációs értékkel a 7. „korlátozottság a járásban” tétel rendelkezik, és a legkevésbé a 6. „lábfejfájdalom” függ össze az EQ-5D indexértékeivel, de még közepesen erős kapcsolat jellemzi ezt a tételt is. A két alskála közül a funkcióalskála korrelációs együtthatója ( $\mathrm{rs}=0,857$, $\mathrm{p}<0,001)$ magasabb az elégedettségi alskálával szemben ( $\mathrm{rs}=0,770 ; \mathrm{p}<0,001)$.

\section{A saját és a szülöi DSI- és az EQ-5D kérdöivek összefüggéseinek vizsgálata}

A kérdőívek összefüggéseinek vizsgálatát kétoldali egyszázalékos szignifikanciaszinten vizsgáltuk, és a kapott korrelációs együtthatók mindegyike szignifikáns.

Magas korrelációs együtthatókat kaptunk a saját/self $(\mathrm{rs}=0,861, \mathrm{n}=37)$ és a szülői $/$ proxy $(\mathrm{rs}=0,747, \mathrm{n}=$ $19)$ DSI-kérdőívhez rendelt EQ-5D-indexértékek elégedettségi pontszámainak összehasonlítása során.

\section{Megbeszélés}

A gyermekek életminőségének mérése különleges problémát vet fel, mivel nem tudjuk közvetlenül az egyént megkérdezni a saját életminőségéról, és ebben az esetben a szülőtől kell beszerezni az információt. Ez azonban ellentmond annak az elvnek, hogy az életminőség- 
4. táblázat | A DSI-tételek és az EQ-5D dimenziói közötti összefüggés vizsgálatának eredményei (Spearman-korrelációs együtthatók)

\begin{tabular}{|c|c|c|c|c|c|c|c|}
\hline & \multicolumn{5}{|c|}{ Az EQ-5D dimenziói $(\mathrm{n}=37)$} & \multirow{2}{*}{$\begin{array}{l}\text { EQ-5D-index } \\
\text { Spearman } \\
\text { rs }\end{array}$} \\
\hline & & $\begin{array}{l}\text { Mozgékonyság } \\
\text { rs }\end{array}$ & $\begin{array}{c}\text { Önellátás } \\
\text { rs }\end{array}$ & $\begin{array}{l}\text { Szokásos tev. } \\
\text { rs }\end{array}$ & $\begin{array}{c}\text { Fájdalom } \\
\text { rs }\end{array}$ & $\begin{array}{c}\text { Szorongás } \\
\text { rs }\end{array}$ & \\
\hline \multirow{13}{*}{$\begin{array}{l}\text { D } \\
\text { S } \\
\text { I }\end{array}$} & 1 & $0,64^{* * *}$ & $0,35^{*}$ & 0,65 *** & $0,66^{* * *}$ & 0,59 *** & $0,742^{* * *}$ \\
\hline & 2 & 0,61 *** & $0,35^{*}$ & $0,68^{* * *}$ & 0,48 ** & $0,65^{* * *}$ & $0,690 * * *$ \\
\hline & 3 & $0,56^{* * *}$ & $0,39^{*}$ & $0,66 * * *$ & $0,64^{* * *}$ & $0,68^{* * *}$ & $0,733 * * *$ \\
\hline & 4 & $0,40^{*}$ & 0,28 & 0,65 *** & $0,55^{* * *}$ & $0,55^{* * *}$ & $0,616^{* * *}$ \\
\hline & 5 & $0,43^{* *}$ & 0,30 & 0,63 ** * & 0,59 *** & $0,43^{* *}$ & $0,625^{* * *}$ \\
\hline & 6 & $-0,26$ & $-0,13$ & $-0,26$ & $-0,46^{* *}$ & $-0,26$ & $0,389^{*}$ \\
\hline & 7 & 0,80 *** & $0,38^{*}$ & $0,75^{* * *}$ & $0,72 * * *$ & $0,73^{* * *}$ & $0,875^{* * *}$ \\
\hline & 8 & 0,65 *** & $0,36^{* *}$ & $0,56^{* * *}$ & $0,70^{* * *}$ & $0,67^{* * *}$ & $0,805^{* * *}$ \\
\hline & 9 & $0,65^{* * *}$ & $0,34^{*}$ & 0,68 *** & $0,75^{* * *}$ & 0,49 ** & $0,779 * * *$ \\
\hline & 10 & $0,66^{* * *}$ & $0,37^{*}$ & $0,74^{* * *}$ & $0,80^{* * *}$ & $0,57^{* *}$ & $0,821^{* * *}$ \\
\hline & $\mathrm{E}$ & 0,57 ** * & $0,38^{*}$ & $0,76^{* * *}$ & $0,66^{* * *}$ & $0,66^{* * *}$ & $0,770^{* * *}$ \\
\hline & $\mathrm{F}$ & $0,69 * * *$ & $0,37^{*}$ & $0,69 * * *$ & 0,81 *** & $0,64 * * *$ & $0,857 * * *$ \\
\hline & $\mathrm{T}$ & $0,68 * * *$ & $0,38^{*}$ & $0,76 * * *$ & $0,78^{* * *}$ & $0,68^{* * *}$ & $0,861^{* * *}$ \\
\hline
\end{tabular}

Megjegyzés: A szürke jelölés a szignifikáns kapcsolat hiányát jelenti.

${ }^{*} \mathrm{p}<0,05 ;{ }^{* *} \mathrm{p}<0,01 ;{ }^{*}{ }^{*} \mathrm{p}<0,001$

DSI = Dongaláb Specifikus Mérőeszköz; $\mathrm{E}$ = elégedettségi alskála; $\mathrm{F}=$ funkcióalskála; $\mathrm{T}$ = teljes DSI-kérdő́iv

kérdőíveknek az egyéni, szubjektív tapasztalásokra kell fókuszálniuk [7, 30-32]. Guyett és mtsai szerint a szülők válaszai 11 éves kor alatt még pontosak, a gyermek véleményével jól korrelálnak, viszont 11 éves kor felett már nem értékelik megfelelően a gyermek életminőségét [33]. Ennek megoldásaként univerzális markerek használata ajánlott, vagy külön vizsgálat az egyes korcsoportoknál [34]. Vizsgálatunkban az egyes korcsoportok megállapítása során elsődleges szempont volt, hogy meghatározzuk azt az életkort (12 év), amelytől már az érintett egyén képes lehet nyilatkozni a saját életminőségéről, illetve ettől fiatalabb gyermekek esetén a szülők még megfelelően értékelik gyermekük életminőségét. Ugyanezt az életkori határt Chesney és mtsai 16 éves korban állapították meg, azonban ezt nem vizsgálták tovább [8]. Az életkori eltérések miatt a 12-17,99 éves korosztály esetében mind a saját, mind pedig a szülői értékelést elemeztük. A szülői kérdőívek esetén szükség volt egy minimális életkori határ megállapítására is (2 év), a cipőviselési szokásokra, a „korlátozottságra a futásban” irányuló kérdések miatt.

A saját és a szülői DSI-kérdőív értékelése során hasonló értékeket kaptunk, amikor a dongalábbal élők életminőségének a leginkább és a legkevésbé érintett területére kerestük a választ. A 10 tétel közül a leginkább a „lábfejfájdalom” és a „megfelelő cipő beszerzése” befolyásolta az életminőségüket, a legkevésbé pedig a „panaszok mérsékelt testmozgás során” - a korlátozottság a járásban - és a „csúfolás” jelentett korlátozást.

A 12-11,99 év közöttiek esetén a saját (self) és a szülői (proxy) DSI-kérdőívek pontértékeinek összehasonlítása során a 10 tétel közül a „lábfejfájdalom” mutatta a legnagyobb különbséget, mert a szülők sokkal jobbnak ítélték meg (10,3 pont), vagy nem tudtak gyermekük lábfejfájdalmáról. A két alskála külön-külön történő értékelése során azt kaptuk, hogy a szülők elégedetlenebbek gyermekük lábának állapotával (-2,1 pont), mint ők maguk, viszont gyermekük lábának funkcióját jobbnak vélték (+15,1 pont), és ez a fájdalom eltérő megítéléséból adódik. Az átlagos pontértékek közötti különbség ellenére szignifikáns összefüggéseket és magas korrelációs együtthatókat kaptunk a szülői és a saját elégedettség- és funkcióalskála, illetve a két teljes skála között. A kapott együtthatók mindegyike 0,6 fölötti, és a két teljes skála összefüggése a 0,87 korrelációs együtthatóval rendelkezik, vagyis lényegében a szülő és a gyermek által kitöltött kérdőív magas fokú egyezést mutat.

A dongalábbal élők életminőségének mérésére - hazai környezetbe - adaptált teljes kérdőívek belső validitása 0,8 feletti értéket mutat (saját DSI: 0,923, proxy DSI: 0,8972), az egyes alskálák Cronbach-alfa-értéke pedig 0,738 és 0,907 között mozog. Bor és mtsai a DSI-kérdőív megbízhatóságát 0,676 Cronbach-alfa-értékben állapították meg, amely lényegesen alacsonyabb az általunk kapottaktól [22]. Dietz és munkatársainak Cronbach-alfa-értékei a következők: teljes skála 0,85, funkcióalskála 0,78 és az elégedettségi alskála 0,74 , ami már hasonló megbízhatóságról tanúskodik [23].

A külső validitás vizsgálata során a saját DSI- és az EQ-5D kérdőívek közötti összefüggéseket vizsgáltuk a 10 DSI-tételhez rendelve egyrészt az EQ-5D kérdőív egyes dimenzióit, másrészt pedig az EQ-5D indexérté- 
keit. Az EQ-5D kérdőív 5 dimenziója közül az önellátást jellemezte a legalacsonyabb szignifikáns összefüggés a 10 tétellel, és mindez összhangban van a tapasztalattal, hiszen az önellátást nem befolyásolja sem a dongaláb, sem pedig az azzal járó korlátozások. Viszont a „szokásos tevékenység” és a „fájdalom” dimenziók a 10 tétel közül 9 DSI-tétellel szoros összefüggést mutatnak. A kivételt mindkét esetben a „fájdalom” DSI-tétel jelenti. A 10 DSI-tétel közül a 6., fájdalomra vonatkozó tétel a többi 9 tételtől meglehetősen eltérő módon, mind az 5 EQ-5D-dimenzió esetén fordított összefüggést mutat, de csak a fájdalom esetén szignifikáns az összefüggés. Ez a különbség az egyes DSI-tételek EQ-5D-indexekhez való viszonyítása során is mutatkozik. A 6. tétel pontozásának különbözőségére vonatkozó hátrányra korábban már utaltunk, mely magyarázata lehet a fenti eltéréseknek. A lábfejfájdalomra vonatkozó DSI-kérdéstől eltekintve a DSI-kérdőív és az EQ-5D-index korrelációs együtthatója $(\mathrm{p}<0,001, \mathrm{rs}=0,861)$ szignifikáns, erős összefüggést jelez.

\section{Következtetések}

Kutatásunk a dongalábbal élők életminőségének mérésére szolgáló, nemzetközileg legelismertebb mérőeszköz, a „Clubfoot Disease-Specific Instrument” - „Dongaláb Specifikus Mérőeszköz” kérdőív hazai adaptálására irányult, amelynek segítségével mérhetővé válik a kezelés eredményessége.

A dongalábbal élők életminőségére irányuló vizsgálattal értékes adatokat nyertünk arra vonatkozóan, hogy a kezelés és a gondozási tevékenység során mely területre szükséges figyelmet szentelni. Elsődlegesen a lábfejfájdalom befolyásolja a dongalábbal élők életminőségét, és ezzel a gyakorlati tapasztalatok és a nemzetközi szakirodalom is egyezőséget mutat [24]. Mindemellett természetesen a kezelés során elsődleges cél a fájdalommentes, illetve megfelelő lábformával és -funkcióval rendelkező láb elérése volt (és lesz is). Nagyon fontos a megfelelő cipő beszerzése, amely már elsősorban a cipőgyártás feladata, viszont a szoros ortopéd szakorvosi együttmúködés eredménye.

A DSI-kérdőív 10 tétele könnyen érthető, megbízható, magas belső és megfelelő külső validitással rendelkezik, amely az objektív paraméterek mellett a beteg szubjektív megítélését fogja tükrözni. A mérőeszköz hazai adaptálása sikeresnek bizonyult, és hozzájárult a dongalábbal élő betegek életminőségének megismeréséhez.

Anyagi támogatás: A közlemény megírása, illetve a kutatómunka anyagi támogatásban nem részesült.

Szerzôi munkamegosztás: B.-B. A.: K. P. A. iránymutatásával készült a statisztikai elemzés. V. L. segítséget nyújtott a kérdőív fordításában és a kézirat megfogalmazásában és formázásában. H. Sz. a szakirodalomkutatásban és -feldolgozásban vett részt. K. J. biztosította az ortopédiai szakmai hátteret és a beteganyagot. P. H. koordinálta az életminőségre irányuló vizsgálatot. A szerzők a cikk végleges változatát valamennyien elolvasták és jóváhagyták.

Érdekeltségek: A szerzőknek nincsenek érdekeltségeik.

\section{Irodalom}

[1] Csáky-Szunyogh M, Horváth-Puhó E, Pálffy Gy, et al. Mandatory reporting and monitoring the reasons of congenital malformations. [A veleszületett fejlődési rendellenességek és a kóroki monitor bejelentésének rendjéről. Módszertani útmutató.] Országos Szakfelügyeleti Módszertani Központ, Szekszárd, 2007. [Hungarian]

[2] Bohner-Beke A, Balku E, Leidecker E, et al. Frequency of congenital structural clubfoot in Hungary. [A veleszületett strukturális dongaláb gyakorisága hazánkban 2004-2009 között.] Magyar Ortopéd Társaság 55. Kogresszusa, Győr, 2012. június 14-16.

[3] Radler C, Mindler GT, Riedl K, et al. Midterm results of the Ponseti method in the treatment of congenital clubfoot. Int Orthop. 2013; 37: 1827-1831.

[4] Sxtersdal C, Fevang JM, Bjørlykke JA, et al. Ponseti method compared to previous treatment of clubfoot in Norway. A multicenter study of 205 children followed for 8-11 years. J Child Orthop. 2016; 10: 445-452.

[5] Porecha MM, Parman DS, Chavda HR. Mid-term results of Ponseti method for the treatment of congenital idipathic clubfoot (A study of 67 clubfeet with mean five year follow-up). J Orthop Surg Res. 2011; 6: 3.

[6] Duffy CM, Salazar JJ, Humphreys L, et al. Surgical versus Ponseti approach for the management of CTEV: a comparative study. J Pediatr Orthop. 2013; 33: 326-332.

[7] Slevin ML, Plant H, Lynch D, et al. Who should measure quality of life, the doctor or the patient? Br J Cancer 1988; 57: 109112.

[8] Chesney D, Barker S, Maffuli N. Subjective and objective outcome in congenital clubfoot; a comparative study of 204 children. BMC Muskuloskelet Disord. 2007; 8: 53.

[9] Horn RV. Statistical indicators for the economic and social sciences, Cambridge. Cambridge University Press, 1993.

[10] Veenhoven R. The utility of happiness. Social Indicators Research 1988; 20: 333-354. http://www2.eur.nl/fsw/research/ veenhoven/Pub1980s/88a-full.pdf (2016-07-16).

[11] Veenhoven R. The study of life satisfaction. In: Saris WE, Veenhoven R, Scherpenzeel AC, et al. (eds.) A comparative study of satisfaction with life in Europe. Eötvös University Press, Budapest, 1996; pp. 11-48. http://www2.eur.nl/fsw/research/ veenhoven/Publ990s/96d-full.pdf (2016-07-18)

[12] Vennhoven R. Developments in satisfaction-research. Social Indicators Research 1996; 37: 1-46. http://www2.eur.nl/fsw/ research/veenhoven/Publ990s/96a-full.pdf (2016-08-01)

[13] Kiss S, Terebessy T, Horváth N, et al. Treatment of clubfoot with the Ponseti method. [A dongaláb kezelése Ponseti-módszerrel.] Lege Artis Med. 2014; 24: 173-179. [Hungarian]

[14] Móok K, Kovács Zs, Rigó A, et al. The psychometric properties of the Hungarian version of the EORTC QLQ-BR23 questionnaire. [Az EORTC QLQ-BR23 magyar változatának pszichometriai jellemzői.] Alkalmazott Pszichológia 2014; 14: 45-58. [Hungarian]

[15] Godányi Zs, Rigó A. The main predictive factors of quality of life in chronic respiratory diseases. [Az életminőség kiemelkedő magyarázóváltozója krónikus légúti betegségekben.] Alkalmazott Pszichológia 2014; 14: 73-88. [Hungarian] 
[16] Rigó A, Nagy D, Bíró M, et al. Quality of life in coeliac disease. [Életminőség lisztérzékenységben.] Alkalmazott Pszichológia 2014; 14: 117-131. [Hungarian]

[17] Minkin T. A biopsychosocial perceptive on health-related quality of life in rheumatoid arthritis. [Az egészséggel összefüggó életminőség biopszichoszociális szemlélete sokízületi gyulladásban.] Alkalmazott Pszichológia 2014; 14: 133-148.

[18] Lovas K, Koó É, Whalley D, et al. The validation of a disease specific quality of life instrument in patients with psoriatic arthritis. [Az arthritis psoriaticában szenvedő betegeknek kidolgozott életminőség-kérdő́ív magyarországi adaptációja.] Lege Artis Med. 2002; 12: 389-395. [Hungarian]

[19] Lovas K, Géher P, Whalley D, et al. Hungarian adaptation of a disease-specific quality-of-life questionnaire in patients with ankylosing spondylitis. [Betegségspecifikus életminőség kérdőív magyar adaptációja. Spondylitis ankylopoeticában szenvedő betegek részére.] Orv Hetil. 2002; 143: 1893-1897.

[20] Roye BD, Vitale MG, Gelijns AC, et al. Patinent-based outcomes after clubfoot surgery. J Pediatr Orthop. 2001; 21: 42-49.

[21] Vitale MG, Choe JC, Vitale MA, et al. Patient-based outcomes following clubfoot surgery: A 16-year follow-up study. J Pediatr Orthop. 2005; 25: 533-538.

[22] Bor N, Coplan JA, Herzenberg JE. Ponseti treatment for idiopathic clubfoot: Minimum 5-year followup. Clin Orthop Relat Res. 2009; 465: 1263-1270.

[23] Dietz FR, Tyler MC, Leary KS, et al. Evaluation of a diseasespecific instrument for idiopathic clubfoot outcome. Clin Orthop Relat Res. 2009; 467: 1256-1262.

[24] Graf A, Hassani S, Krzak J, et al. Long-term outcome evaluation in young adults following clubfoot surgical release. J Pediatr Orthop. 2010; 30: 379-385.

[25] Church Ch, Coplan JA, Poljak D, et al. A comprehensive outcome comparison of surgical and Ponseti clubfoot treatments with reference to pediatric norms. J Child Orthop. 2012; 6: 51-69.

[26] Péntek M. Health status and burden of illness of rheumatoid arthritis patients in Hungary. PhD thesis. [Rheumatoid arthritises betegek egészségi állapota és betegségterhe Magyarországon. Doktori értekezés.] Semmelweis Egyem, Patológiai Tudományok Doktori Iskola, Budapest, 2007. [Hungarian]

[27] Baji P, Brodszky V, Rencz F, et al. Health state of Hungarian population between 2000-2010. [A magyar lakosság egészségi állapota 2000-2010 között.] Orv Hetil. 2015; 156: 2035-2044. [Hungarian]

[28] Péntek M, Kosztolányi Gy, Melegh B, et al. Health related quality of life and disease burden of patients with cystic fibrosis and their caregivers: Results of the European BURQOL-RD survey in Hungary. [Cystás fibrosissal elő betegek és gondozóik életminősége és betegségterhei: a BURQOL-RD európai felmérés magyarországi eredményei.] Orv Hetil. 2014; 155: 16731684. [Hungarian]

[29] Szokolszky Á. Research methods in psychology. [Kutatómunka a pszichológiában.] Osiris Kiadó, Budapest, 2004. [Hungarian]

[30] Bowling A. Measuring disease, Buckingham. Open University Press, Buckingham, PA, 1995.

[31] Reich W, Herjanic B, Welner Z, et al. Development of a structured psychiatric interview for children: agreement on diagnosis comparing child and parent interviews. J Abnorm Child Psychol. 1982; 10: 325-336.

[32] Herjanic B, Reich W. Development of a structured psychiatric interview for children: agreement between child and parent on individual symptoms. J Abnorm Child Psychol. 1982; 10: 307324.

[33] Guyatt GH, Juniper E, Griffith LE, et al. Children and adult perceptions of childhood asthma. Pediatrics 1999; 2: 165-168.

[34] Vetró Á, McGuiness D, Fedor I, et al. Results from an epidemiological study. [Iskolás korú gyermekek viselkedési problémáinak epidemiológiai vizsgálata Szegeden.] Psychiatr Hung. 1997; 12: 193-200. [Hungarian]

(Bohner-Beke Aliz, Baja, Szivárvány u. 28/D, 6500 e-mail: bohner.beke@gmail.com)

\section{"Nihil est tam perfectum, quod non habeat defectum." (Nincs oly tökély, hogy benne egy kis hiba ne lenne.)} feltéve, hogy az eredeti szerző és a közlés helye, illetve a CC License linkje és az esetlegesen végrehajtott módosítások feltüntetésre kerülnek. 